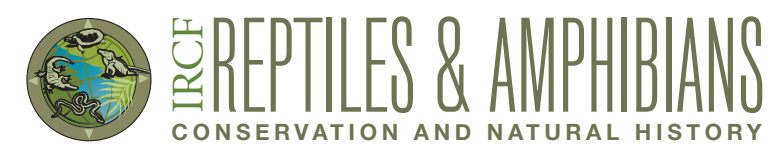

\title{
Use of Cow Manure by Two Sympatric Species of Toads in the Northwestern Dominican Republic
}

\author{
Miguel A. Landestoy T. ${ }^{1}$, Robert Ortíz ${ }^{1}$, and Patricia Torres ${ }^{2}$ \\ 1'Sociedad Ornitológica de la Hispaniola, Santo Domingo, República Dominicana (hispanioland@gmail.com) \\ ${ }^{2}$ Escuela de Biología, Universidad Autónoma de Santo Domingo, República Dominicana (pattorresp@gmail.com)
}

$\mathrm{T}_{\mathrm{s}}$

The bufonid genus Peltophryne forms a monophyletic group endemic to the West Indies (Frost et al. 2006; Pramuk 2006). Three endemic Hispaniolan species are currently recognized (Henderson and Powell 2009; Powell 2012), two of which (Peltophryne fluviatica and P. fracta) have restricted ranges (Hedges et al. 2004a, 2004b). The third, the Southern Crested Toad (P. guentheri), is widely distributed mainly along major lowland valleys (Henderson and Powell
2009), although it can reach elevations up to 270 and $360 \mathrm{~m}$ (El Matadero; MAL, pers. obs.) on the northern and southern slopes of the Cordillera Central, respectively. Introduced Cane Toads (Rhinella marina) are abundant in mesic areas and microhabitats at lower elevations throughout Hispaniola. Peltophryne guentheri is a medium-sized toad with a snout-tovent length (SVL) to $73.8 \mathrm{~mm}$ in males (Schwartz 1972) and $101 \mathrm{~mm}$ in females (Schwartz and Henderson 1991). Most

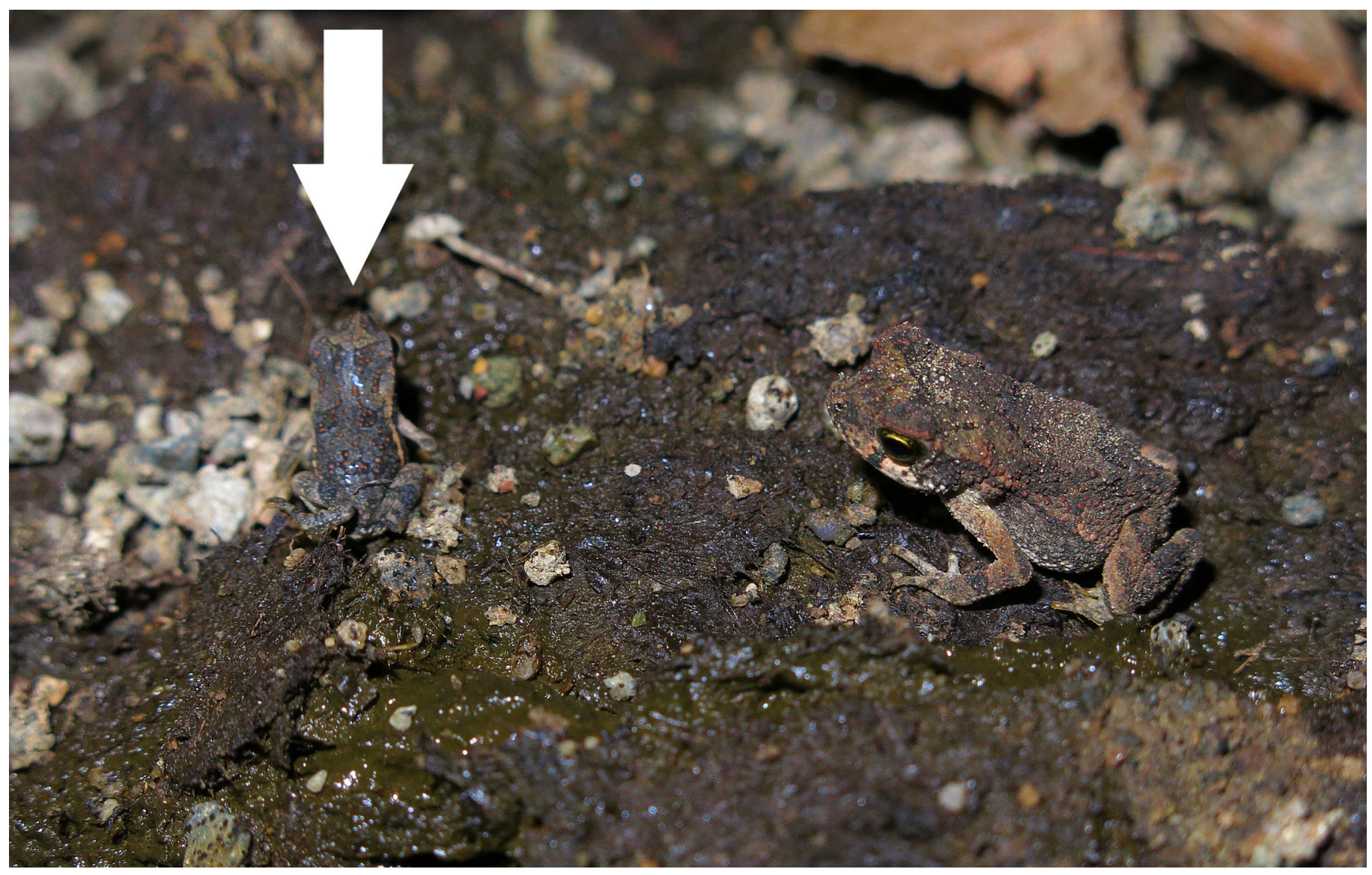

Fig. 1. A metamorph (arrow) and a toadlet of the Southern Crested Toad (Peltophryne guentheri) sitting on a "cow pie" in Arroyo Bellaco. Photograph by Miguel A. Landestoy. 
adult Cane Toads range in size from 85 to $150 \mathrm{~mm} \mathrm{SVL}$ (Easteal 1986) but can reach $230 \mathrm{~mm}$ (Rivero 1998). Parsons (1995) provided the only available information on the diet of $P$. guentheri. That study was based on stomach contents of preserved specimens. No field studies have been conducted on feeding behavior (Henderson and Powell 2009). In the West Indies, $R$. marina is known to feed on beetles (including scarabeids; Wolcott 1937) or "almost anything" (Long 1974), and has been recorded exploiting the artificial night light niche (Breuil 2002; MAL, pers. obs.).

During fieldwork in Arroyo Bellaco, $1.5 \mathrm{~km}$ ESE of the village of Caimito, Santiago Rodríguez Province, Dominican Republic $\left(19.4896^{\circ} \mathrm{N},-71.27009^{\circ} \mathrm{E}\right.$, elevation $\left.160 \mathrm{~m}\right)$, on 9 August and 5 September 2014, at $2100 \mathrm{~h}$ (temperature 26.3 ${ }^{\circ} \mathrm{C}$, relative humidity $\left.76.1 \%\right)$ and $1925 \mathrm{~h}\left(26.9^{\circ} \mathrm{C}, 73.3 \%\right)$, respectively, we observed metamorphs and toadlets of the Southern Crested Toad and the Cane Toad sitting on and near piles of cattle manure (Fig. 1) within 2-4 m of the stream bank. Local residents bring cattle from neighboring semi-arid farms to the stream each day to drink (Fig. 2). We saw as many as six young $P$. guentheri and two $R$. marina using a sit- and-wait foraging strategy to capture insects on manure. On the two nights, we counted three and five "cow pies," respectively, on which toadlets were sitting. Piles were fresh with a thin, moderately firm crust, although cattle had stepped on some, exposing the moist interior. Because we observed prey capture and anurans using livestock manure as a foraging site has been reported for Mexican Spadefoots (Spea multiplicata; Barragán-Ramirez et al. 2014) and Squirrel Treefrogs (Hyla squirrella; Carr 1940), we assume that the association with manure piles is a foraging strategy. However, because the piles hold moisture and heat, toads also might be exploiting them to avoid desiccation or for warmth (González-Bernal et al. 2012).

We have monitored breeding choruses of both species along this section of the stream, and observed tadpoles on 21 July ( $P$. guentheri) and 9 August ( $R$. marina). In the course of 11 trips to several rivers and tributaries in the general area, we noticed that recently metamorphosed individuals remain close to the stream before dispersing into adjacent habitats after two to three weeks. Leaf litter accumulates along the streambed where we saw tadpoles and an adjacent narrow

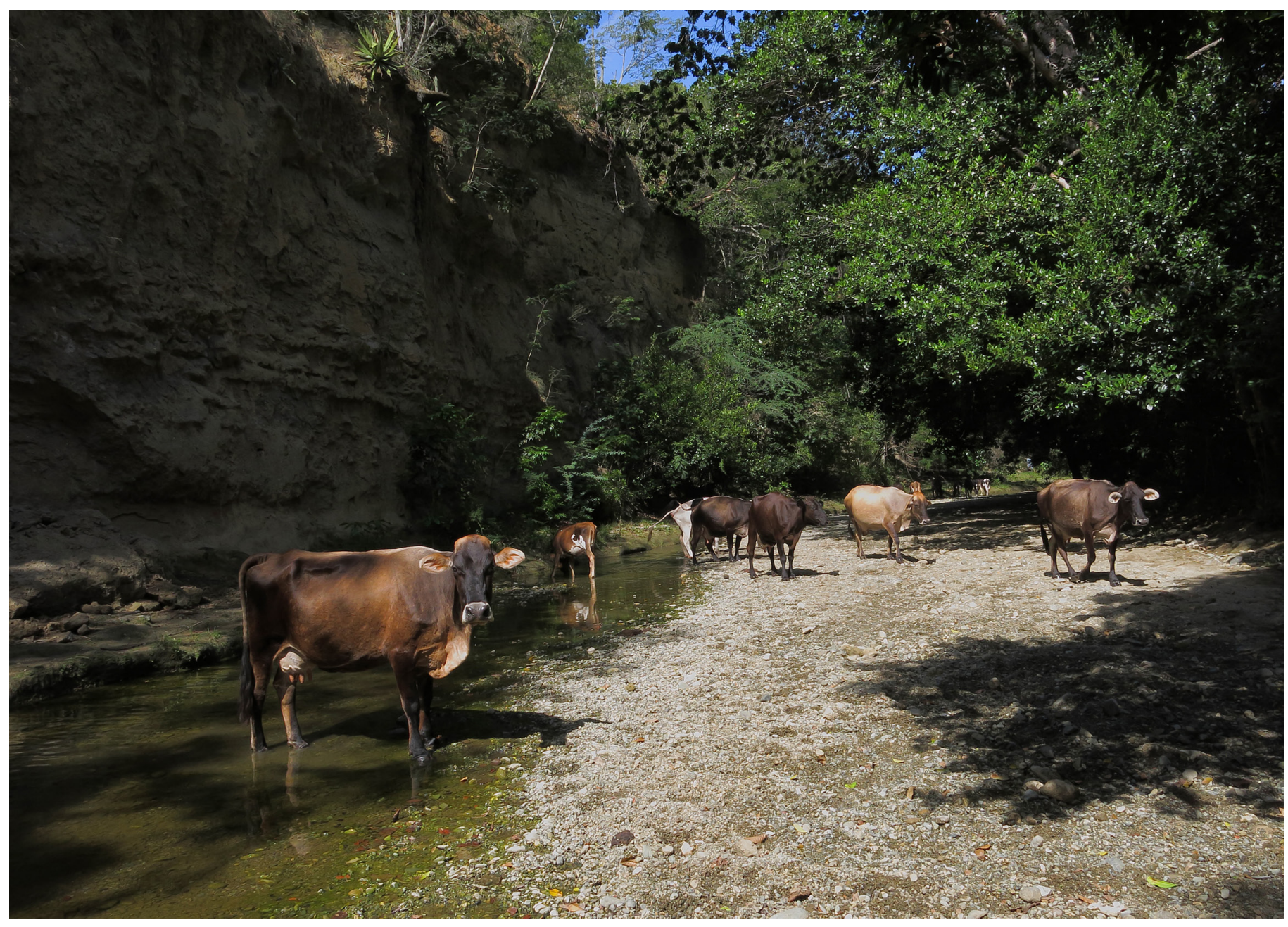

Fig. 2. Local residents bring cattle from neighboring semi-arid farms to Arroyo Bellaco each day to drink. The adjacent strip of riparian forest is at the right. Photograph by Miguel A. Landestoy. 


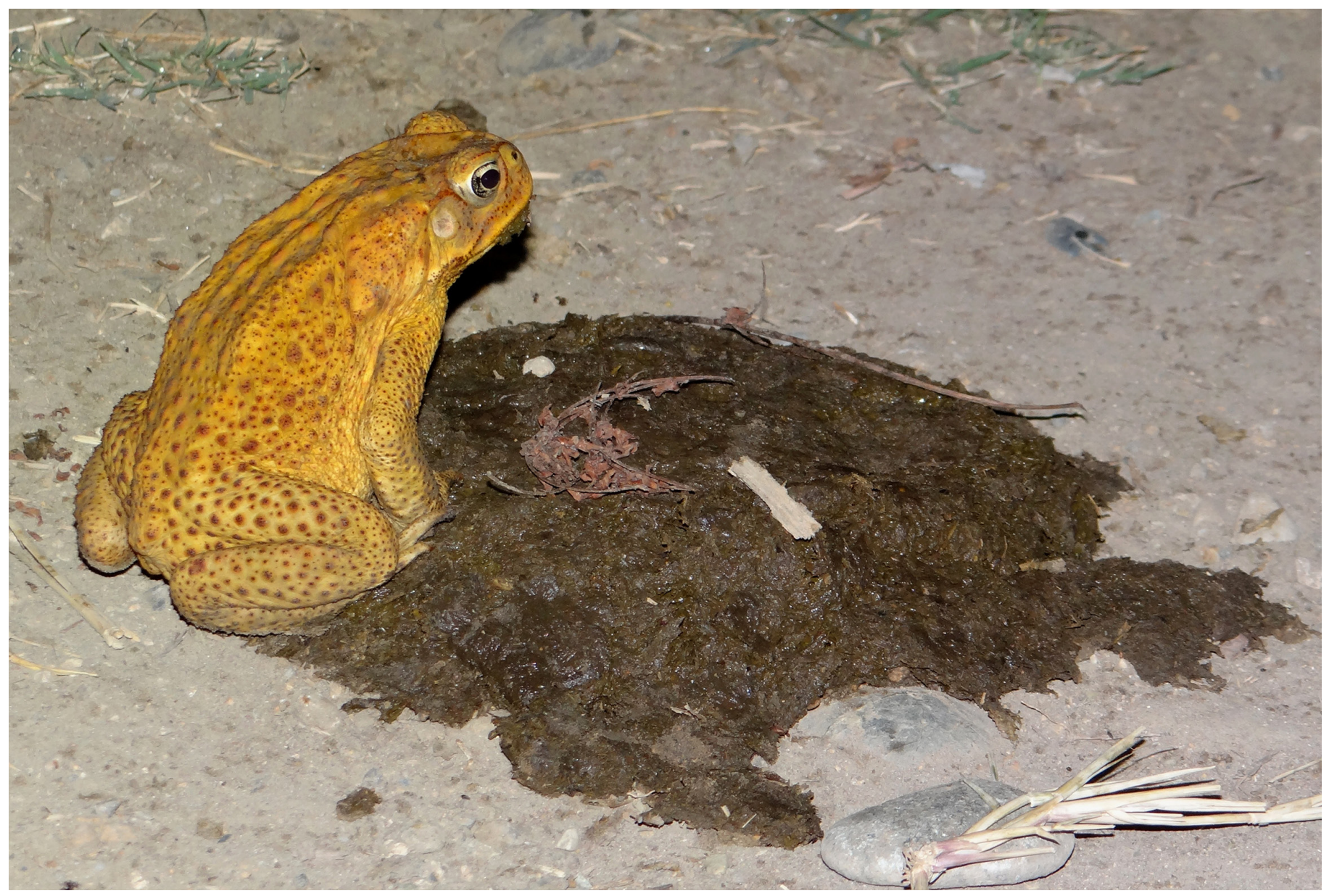

Fig. 3. An adult Cane Toad (Rhinella marina) foraging on cow manure. Photograph by Robert Ortíz.

strip of riparian forest is bordered by a forest clearing $-20 \mathrm{~m}$ from the shoreline.

We frequently find adult Cane Toads sitting on or adjacent to piles of manure (Fig. 3) in the same general area. These toads often have feet and mouths covered in fresh dung. While examining the manure, we also found introduced scarabeid dung beetles (Digitonthophagus gazella; Fig. 4 ). We dissected the stomach of one adult gravid female Cane Toad (containing oocytes weighing $48 \mathrm{~g}$ ) and found dung beetles to be the most abundant prey item $(\mathrm{N}=106)$. Although both species of toads share the same breeding sites, we have not found adult $P$. guentheri foraging in this microhabitat, which is suggestive of ontogenetic resource partitioning between these two bufonids.

\section{Acknowledgements}

We thank the Ministerio de Medio Ambiente y Recursos Naturales of the Dominican Republic for issuing a research permit for the project "Ecology and Conservation of Hispaniolan Bufonids (Peltophryne)" and the Rufford Foundation for funding it. Robert E. Woodruff (Florida State Collection of Arthropods) and Brett Rattcliffe (University of Nebraska) confirmed the identification of the dung beetle.

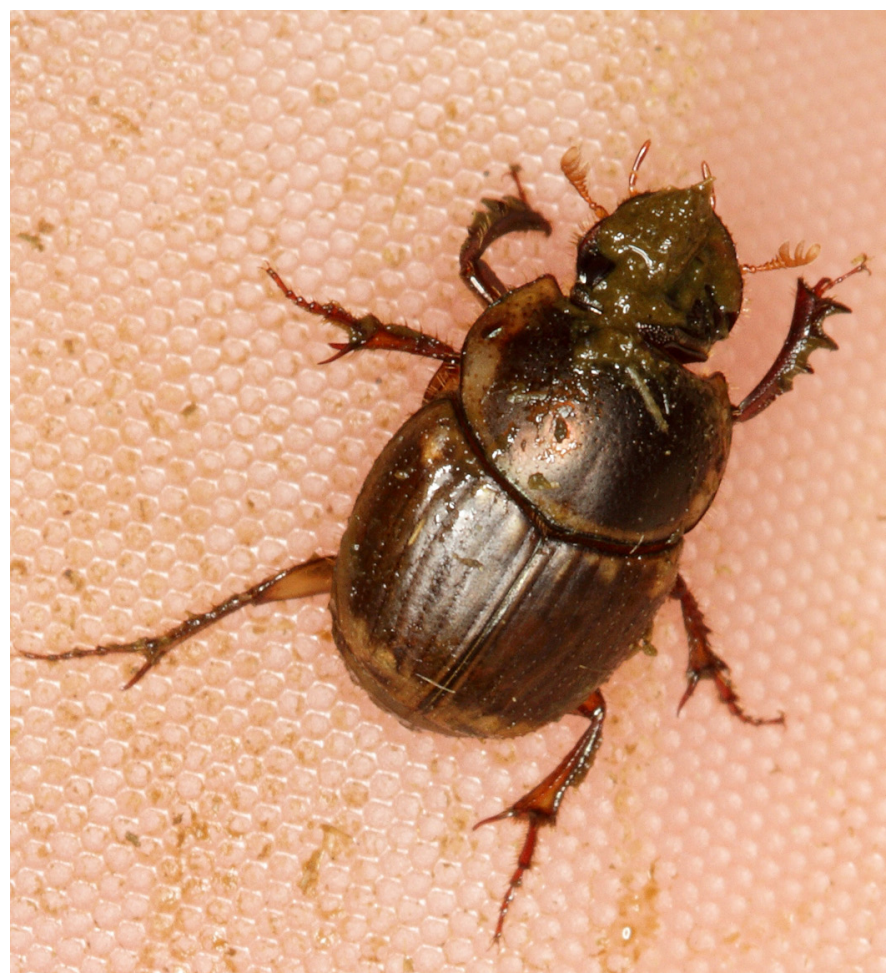

Fig. 4. An introduced dung beetle, Digitonthophagus gazella (Scarabaeidae), found in cow manure. Photograph by Miguel A. Landestoy. 
We also thank the Facebook group "Insectos Caribeños" for helpful comments and interactions that led to the identification of the dung beetle.

\section{Literature Cited}

Barragán-Ramírez, J.L., J.J. Ascencio-Arrayga, F. Rodriguez-Ramírez, and J.L. Navarrete-Heredia. 2014. Spea multiplicata (Mexican Spadefoot). Foraging Site Selection. Herpetological Review 41:115-116.

Breuil, M. 2002. Histoire naturelle des amphibiens et reptiles terrestres de l'Archipel Guadeloupéen. Guadeloupe, Saint Martin, Saint Barthélemy. Patrimoines Naturels, Paris 54:1-339.

Carr, A.F., Jr. 1940. A contribution to the herpetology of Florida. University of Florida Publication in Biological Science, Series 3:1-118.

Easteal, S. 1986. Bufo marinus. Catalogue of American Amphibians and Reptiles 395:1-4.

Frost, D.R., T. Grant, J.N. Faivovich, R.H. Bain, A. Haas,

C.F.B.

Haddad, R.O. de Sá, A. Channing, M. Wilkinson, S.C. Donnellan, C.J. Raxworthy, J.A. Cambel, B.L. Blotto, P. Moler, R.C. Drewes, R.A. Nussbaum, J.D. Lynch, D.M. Green, and W.C. Weeler. 2006. The amphibian tree of life. Bulletin of the American Museum of Natural History 297:1-370.

González-Bernal, E., M. Greenlees, G.P. Brown, and R. Shine. 2012. Cane Toads on cowpats: Commercial livestock production facilitates toad invasion in tropical Australia. PLoS ONE 7: e49351.

Hedges, S.B., S.J. Incháustegui, M. Hernández, and R. Powell. 2004a. Peltophryne fracta. In: IUCN 2011. IUCN Red List of Threatened Species. <www.iucnredlist.org>.
Hedges, S.B., S.J. Incháustegui, M. Hernández, and R. Powell. 2004b. Peltophryne fluviatica. In: IUCN 2011. IUCN Red List of Threatened Species. <www.iucnredlist.org>.

Henderson, R.W. and R. Powell. 2009. Natural History of West Indian Reptiles and Amphibians. University Press of Florida, Gainesville.

Long, E.G. 1974. The Serpent's Tale: Reptiles and Amphibians of St Lucia. Iouanaloa Series No. 2. University of West Indies Extra Mural Department, The Morne, St. Lucia.

Parsons, K. J. 1995. Peltophryne guentheri (NCN). Diet. Herpetological Review 26:202.

Powell, R. 2012. Hispaniola and Navassa, pp. 131-137. In: R. Powell and R.W. Henderson (eds.), Island lists of West Indian amphibians and reptiles. Bulletin of the Florida Museum of Natural History 51:87-168.

Pramuk, J.B. 2006. Phylogeny of South American Bufo (Anura: Bufonidae) inferred from combined evidence. Zoological Journal of the Linnean Society 146:407452.

Rivero, J.A. 1998. Los Anfibios y Reptiles de Puerto Rico. Secunda edición revisada. The Amphibians and Reptiles of Puerto Rico. Second edition revised. Universidad de Puerto Rico, San Juan.

Schwartz, A. 1972. The native toads (Anura, Bufonidae) of Hispaniola. Journal of Herpetology 6:217-231.

Schwartz, A. and R.W. Henderson. 1991. Amphibians and Reptiles of the West Indies: Descriptions, Distributions and Natural History. University of Florida Press, Gainesville.

Wolcott, G. W. 1937. What the giant Surinam toad, Bufo Marinus (L.) is eating now in Puerto Rico. University of Puerto Rico Journal of Agriculture 21:79-84. 